\title{
Effect of Vegetation Types on the Physicochemical Properties of Soils under Different Land Use
}

\author{
Amonum. J. I. ${ }^{1,2^{*}}$, ISSA, S. ${ }^{1}$, Amusa, T. O. ${ }^{1}$ \\ ${ }^{1}$ Department of Forest Resources Management, Faculty of Agriculture, University of Ilorin, Nigeria. \\ ${ }^{2}$ Department of Forest Production and products, College of Forestry and Fisheries, Federal University of \\ Agriculture Makurdi, Nigeria.
}

*Corresponding Author: Amonum. J. I., Department of Forest Resources Management, Faculty of Agriculture, University of Ilorin, Nigeria.

\begin{abstract}
Proper utilization of land is essential to soil quality maintenance and sustainable land development. This study was conducted to evaluate effects of different vegetation types under land use management on physicochemical characteristics of soils in the University of Ilorin, Nigeria. Composite soils samples under different vegetation types used were collected at the depth of 0-30 cm from sampling plots of $25 m \times 25 \mathrm{~m}$; using random sampling design. The vegetation types used in the study area include: Tectona grandis (teak) plantation, Forestreserve, Jatropha curcas plantation and Farmland. The soil samples were analyzed in the laboratory to determine the soil physicochemical properties. Soil properties were analyzed using One way Analysis of Variance, and the relationship among the soil physicochemical properties were determined using correlation analysis. Results showed that natural forest on the overall accumulated more nutrients than teak plantation, Jatropha plantation and farmland. Farmland has the least concentration of chemical properties, for soil organic carbon (0.37\%), total nitrogen (0.35\%), available phosphorus (0.34\%), calcium $(0.57 \mathrm{cmol}(+) / \mathrm{kg})$, potassium $(0.2757 \mathrm{cmol}(+) / \mathrm{kg})$ and sodium $(0.0657 \mathrm{cmol}(+) / \mathrm{kg})$, when compared to Forestland, Jatropha and Teak plantations. This indicated that there is an overall change towards the direction of loss of soil fertility under farmland than the other vegetation types. The study further revealed that there was significant $(p<0.05)$ difference in available phosphorus and total nitrogen between and among the different vegetation types. However, there was no significant difference $(p>0.05)$ in silt fraction between and among the vegetation types. The results obtained from the present study indicated that the different vegetation types have affected the soils at a various rate. It could be concluded that the soil quality and health were maintained relatively under the forestland, whereas, the influence on most parameters were very low on the soil of farmland indicating the need for employing integrated soil fertility management. It is recommended that appropriate and integrated land management options for different vegetation types under land uses are required to sustain agricultural productivity while protecting the environment.
\end{abstract}

Keywords: Chemical, Forest, Physical, Plantation, Property, Soil, Vegetation.

\section{INTRODUCTION}

Lands have been utilized intensively for all purposes at the expense of their suitability, which have resulted in massive land degradation (Senjobi and Ogunkunle, 2011; Ahukaemere et al., 2012). Land degradation has serious impact on soil physical and chemical properties especially the infiltration, bulk density, organic matter, porosity and aggregate stability causing their compaction and erosion (Tukahirwa, 2003). It has been reported that unsystematic changes in land use predisposes it to several environmental problems such as desertification, acidification, eutrophication, greenhouse effect that cause climate change and biodiversity loss (Reichstein, 2008).

Over the years, soil biodiversity and its physical properties that control water movement and retention in the soils are largely affected due to human, animal activities as well as use of machine(s) for soil tillage purposes (Tilahun, 2007). The anthropogenic changes in land use have altered the characteristics of the Earth's surface, leading to changes in soil physicochemical properties such as soil fertility, soil erosion sensitivity and content of soil moisture (Abad et al., 2014). These changes may be caused by soil compaction that reduces soil volume and consequently lowers soil productivity and environmental quality (Abad et al., 2014). As the fertility of soil declines, soil structure weakens and the soil becomes susceptible to erosion (Adetunji, 2004). 
Soil physical and chemical properties play a vital role in transport and reaction of water, solutes and gases in soils. Their knowledge is very important in understanding soil behavior to applied stresses, transport phenomena in soils; however, little is known on the soil physicochemical properties in the different vegetation types of the study area. Baseline information on effect of vegetation on soil in the study area, which form essential component of any sustainable land use systems, are yet unavailable in the study area.

It woul be difficult to evolve a sound sustainable use of soil resources strategy, especially to enhance land productivity for the study area without adequate knowledge of soil physical and chemical properties. Hitherto, there is dearth of information about soil quality in the different vegetation types. Thus, there is need to determine the soil physicochemical properties in order to provides a suitable land management practices, and present appropriate recommendations for optimal and sustainable utilizations of land resources.

The effects of land uses on the environment ranges from minor land cover changes and soil modification to severe desertification, deforestation, erosion, and river encroachment problems. Therefore, there is increasing concern about the land use land cover changes and its negative impacts on soil quality and the environment in many parts of the world due to the current global population growth and economic development. Thus, it is important to have knowledge on the soil physicochemical properties as this may facilitate the formulation of sustainable soil management strategies and effective soil conservation practices in the study area. This study, therefore, provides baseline information on physicochemical properties of soil, which will help to ascertain the status of the soil in the area to ensure an effective management planning.

\section{Methodology}

\subsection{The Study Area}

The study was carried out at the University of Ilorin, situated in Ilorin South, Ilorin. It is located on Latitude $8^{\circ} 30^{\prime}$ and $8^{\circ} 50^{\prime} \mathrm{N}$, and Longitude $4^{\circ} 20^{\prime}$ and $4^{\circ} 35^{\prime} \mathrm{E}$ of the equator, occupying an area of about 468 sq.km. It is situated in the transitional zone within the forest and the guinea savannah regions of Nigeria. The University of Ilorin is located at about $500 \mathrm{~km}$ apart from Abuja, the Nigeria national capital, and $300 \mathrm{~km}$ away from Lagos, Nation's economic capital. Geographically, the study area lies at latitude $8.47 \mathrm{oN}$ and longitude $4.54 \mathrm{oE}$, covering an approximate land mass of 5,000 hectare.

The annual rainfall of the area is between 600 and $1500 \mathrm{~mm}$ with distinct wet and dry seasons of almost six months each. The average relative humidity is $77.50 \%$ and daily sunshine of 7.1 hours. The mean monthly temperatures are very high, varying from $25^{\circ} \mathrm{C}$ to $38^{\circ} \mathrm{C}$ (Olanrewaju, 2009).

The soil of the area is loamy-sand with mean composition of $4 \%, 7 \%$ and $89 \%$ for clay, silt and sand respectively. Sand, which is predominantly large particles, tend to drain quickly and have lower fertility. The $\mathrm{pH}$ ranges between 7.10 and 7.81, Water holding capacity ranges between $0.28 \mathrm{ml} / \mathrm{g}$ and $0.53 \mathrm{ml} / \mathrm{g}$, and the Moisture content ranges from 2.10\% to 5.23\% (Oyeyiola and Agbaje, 2013).

\subsection{Soil Sampling Procedure and Collection}

Soil samplings were collected from four vegetation types under different land use in the study area, to determine their physicochemical properties. The vegetation types used in the study area include: Tectona grandis (teak) plantation, Forestland (forest reserve), Jatropha curcas plantation and Farmland. In each vegetation type (treatment), sampling plots were demarcated into $25 \mathrm{~m}$ x $25 \mathrm{~m}$ from which soil samples were randomly selected in six different areas. The soil samples were collected from 0-30 $\mathrm{cm}$ depth using soil auger. The $30 \mathrm{~cm}$ depth for soil were considered during sampling in order to accommodate mobile nutrients such as nitrogen, where large volumes of soil might be disturbed. For each treatment, one composite soil sample was then prepared from the six different areas with three replicates. The collected soil samples were properly labeled for identification and packed in polythene bags. Samples were air-dried, grounded (using mortar and pestle) and passed through $2 \mathrm{~mm}$ size sieve before laboratory analysis.

\subsection{Laboratory Analysis of Soil Physicochemical Properties}

The soil physical and chemical analysis was carried out at the Soil Analytical Laboratory of the Department of Agronomy, university of Ilorin, Nigeria. Standard laboratory procedures were followed in the analysis of the physicochemical properties considered in the study. 
Particle size distribution of different particle size fractions for soil texture evaluation was determined using Boyoucos hydrometric method as described by (Bouyoucos, 1962; Day, 1965; Gee and Bauder, 1986; Van Reeuwijk, 1992). Soil pH determination was carried out in water (H2O) and potassium chloride $(1 \mathrm{M} \mathrm{KCl})$ suspension in 1:1 (soil solution ratio) was determined using a glass electrode (Van Reeuwijk, 1992). Soil Organic Carbon was determined based on wet-oxidation method as described by Walkley and Black (1934). Total Nitrogen was analyzed using the Kjeldahl digestion, distillation and titration method as described by Black (1965). Available Phosphorus was analyzed by Bray (P-1) acid Fluoride method as outlined by Olsen et al. (1954). Exchangeable bases [Calcium (Ca), Magnesium (Mg), Potassium (K) and Sodium (Na)] were determined after extracting the soil samples by ammonium acetate (1N NH4OAc) at pH 7.0 (Chapman, 1965; Rowell, 1994; Reeuwijk, 2002).

\subsection{Data Analysis}

The Laboratory analytical results on different soil physicochemical properties were computed into Excel spreadsheet (2013), and were then subjected to One way Analysis of Variance using MINITAB 14 to determine the mean, standard deviation and to test for significance among the treatment. Soil properties were compared using Pearson correlation coefficient, and the existence of interrelationships between data set was tested by linear correlation.

\section{Results}

\subsection{Soil Particle Size Distribution to Vegetation Types}

The result of particle size distribution analysis showed there was no significant difference in silt content among the vegetation types. The highest average silt content was recorded under Forestland $(12.67 \%)$ and the lowest in Jatropha plantation $(8.67 \%)$. Silt content showed a significant and positive correlation with Organic carbon $(r=0.66)$, Total Nitrogen $(r=0.61)$, Phosphorus $(r=0.65)$, Calcium $(r=0.60)$ and available Potassium $(r=0.64)$ as shown in Table 4. The textural class for all the four vegetation types was loamy sand, indicating the similarity in parent material.

Sampled soils did not show significant differences in the sand and clay percentages among Teak plantation, Jatropha plantation and Farmland at 0.05 levels (Table 1). However, there were little variations in the particle size composition of the sampled soil at the different vegetation type. Numerically, Jatropha plantation and Farmland have the highest average mean of sand contents (86.76\%), and Teak plantation and Farmland have the least average mean of clay contents (3.91\%) respectively. Likewise, Forestland has the highest average clay content $(7.91 \%)$ and the least average sand content $(79.43 \%)$ respectively as shown in Table 1 . Clay content were positively correlated with Magnesium $(\mathrm{r}=0.60)$ and 53 total Nitrogen $(\mathrm{r}=0.59)$ while sand content was positively and negatively correlated with $\mathrm{pH}(\mathrm{H} 2 \mathrm{O})$ and $\mathrm{Mg} 2+$ having values of $\mathrm{r}=0.68$ and $\mathrm{r}=-0.62$ respectively (Table 4).

Table1. Soil particle size distribution in the study area

\begin{tabular}{|c|c|c|c|c|c|c|}
\hline $\begin{array}{c}\text { Soil } \\
\text { composition }\end{array}$ & \multicolumn{4}{|c|}{ Location } & $\begin{array}{c}\text { F- } \\
\text { values }\end{array}$ & $p$ - values \\
\hline & $\begin{array}{c}\text { Teak } \\
\text { Plantation }\end{array}$ & Forestland & $\begin{array}{c}\text { Jatropha } \\
\text { Plantation }\end{array}$ & Farmland & & \\
\hline$\%$ Silt & $10.00 \pm 0.00^{\mathrm{a}}$ & $12.67 \pm 3.06^{\mathrm{a}}$ & $8.67 \pm 1.16^{\mathrm{a}}$ & $9.33 \pm 1.16^{\mathrm{a}}$ & 3.07 & 0.091 \\
\hline$\%$ Sand & $86.09 \pm 1.16^{\mathrm{a}}$ & $79.43 \pm 2.31^{\mathrm{b}}$ & $86.76 \pm 0.00^{\mathrm{a}}$ & $86.76 \pm 0.00^{\mathrm{a}}$ & 22.93 & 0.000 \\
\hline$\%$ Clay & $3.91 \pm 1.16^{\mathrm{a}}$ & $7.91 \pm 1.16^{\mathrm{b}}$ & $4.57 \pm 1.16^{\mathrm{a}}$ & $3.91 \pm 1.16^{\mathrm{a}}$ & 8.25 & 0.008 \\
\hline $\begin{array}{c}\text { Textural } \\
\text { Class }\end{array}$ & LS & LS & LS & LS & & \\
\hline
\end{tabular}

Means with the same letters are not significantly different from each other.

\subsection{Soil (pH), Organic Carbon, Total Nitrogen and Available Phosphorus on Vegetation Types}

The Analysis of Variance as shown in Table 2 revealed that, the soil $\mathrm{pH}\left(\mathrm{H}_{2} \mathrm{O}\right)$ and $\mathrm{pH}(\mathrm{KCl})$ were significantly affected by vegetation types. Numerically, Jatropha plantation has the highest mean soil $\mathrm{pH}$ in water (7.17) and soil $\mathrm{pH}$ in $\mathrm{KCl}(6.47)$ while Forestland has the least soil $\mathrm{pH}$ in both water (6.30) and $\mathrm{KCl}(5.30) \cdot \mathrm{pH}\left(\mathrm{H}_{2} \mathrm{O}\right)$ was negatively correlated with organic carbon $(\mathrm{r}=-0.70)$, available phosphorus $(r=-0.64)$ and $\mathrm{K}+(\mathrm{r}=-0.69)$ as shown in Table 4. 
Soil Organic Carbon (OC) content in the study area was lower in Farmland with mean composition of $(0.37 \%)$ compared to Teak plantation $(0.49 \%)$, Jatropha plantation $(0.52 \%)$ and Forestland $(1.00 \%)$. There was no significant difference between the plantations, but among the four vegetation types, there was a signicant difference. From Table 4, OC showed a positive and significant relationship with silt $(\mathrm{r}=0.66)$.

Total Nitrogen (TN) and Available Phosphorus (AP) contents showed significant differences $(\mathrm{p}<0.05)$ under soils of different vegetation types with the highest mean $(0.76 \% ; 1.32 \mathrm{mg} / \mathrm{kg})$ and lowest mean $(0.35 \% ; 0.34 \mathrm{mg} / \mathrm{kg})$ contents of both recorded under Forestland and Farmland respectively as shown in Table 2. The result of correlation analysis in Table 4 showed that total nitrogen has a significant and positive relationship with $\mathrm{K}+(\mathrm{r}=0.65)$, Silt $(\mathrm{r}=0.61)$ and Clay $(\mathrm{r}=0.59)$ while Available Phosphorus has a positive relationship with silt $(\mathrm{r}=0.65)$.

Table2. Soil pH, Organic Carbon, Total Nitrogen and Available Phosphorus of the study area

\begin{tabular}{|c|c|c|c|c|c|}
\hline Parameters & Locations & Mean & Std. Deviation & F-value & p-value \\
\hline \multirow[t]{4}{*}{$\mathrm{pH}(\mathrm{H} 2 \mathrm{O})$} & Teak Plantation & $7.00 \mathrm{a}$ & \pm 0.10 & 9.63 & 0.005 \\
\hline & Forestland & $6.30 \mathrm{~b}$ & & \pm 0.17 & \\
\hline & Jatropha Plantation & $7.17 \mathrm{a}$ & & \pm 0.21 & \\
\hline & Farmland & $6.77 \mathrm{ab}$ & & \pm 0.31 & \\
\hline \multirow[t]{4}{*}{$\mathrm{pH}(\mathrm{KCl})$} & Teak Plantation & $5.87 \mathrm{ab}$ & \pm 0.06 & 3.32 & 0.078 \\
\hline & Forestland & $5.30 \mathrm{a}$ & & \pm 0.00 & \\
\hline & Jatropha Plantation & $6.47 \mathrm{~b}$ & & \pm 0.40 & \\
\hline & Farmland & $5.87 \mathrm{ab}$ & & \pm 0.81 & \\
\hline \multirow[t]{4}{*}{$\% \mathrm{OC}$} & Teak Plantation & $0.49 \mathrm{a}$ & \pm 0.00 & 838.58 & 0.000 \\
\hline & Forestland & $1.00 \mathrm{~b}$ & & \pm 0.02 & \\
\hline & Jatropha Plantation & $0.52 \mathrm{a}$ & & \pm 0.03 & \\
\hline & Farmland & $0.37 \mathrm{c}$ & & \pm 0.01 & \\
\hline \multirow[t]{4}{*}{$\% \mathrm{TN}$} & Teak Plantation & $0.65 a$ & \pm 0.03 & 226.79 & 0.000 \\
\hline & Forestland & $0.76 \mathrm{~b}$ & & \pm 0.03 & \\
\hline & Jatropha Plantation & $0.49 \mathrm{c}$ & & \pm 0.01 & \\
\hline & Farmland & $0.35 \mathrm{~d}$ & & \pm 0.01 & \\
\hline \multirow[t]{4}{*}{$\mathrm{AP}(\mathrm{mg} / \mathrm{kg})$} & Teak Plantation & $0.70 \mathrm{a}$ & \pm 0.04 & 515.06 & 0.000 \\
\hline & Forestland & $1.32 \mathrm{~b}$ & & \pm 0.02 & \\
\hline & Jatropha Plantation & $0.61 \mathrm{c}$ & & \pm 0.34 & \\
\hline & Farmland & $0.34 \mathrm{~d}$ & & \pm 0.02 & \\
\hline
\end{tabular}

Means with the same letters are not significantly different from each other.

\subsection{Exchangeable Bases to Vegetation Types}

Table 3 shows the exchangeable bases of the study area. Contents of Calcium (Ca2+) and Magnesium $(\mathrm{Mg} 2+)$ have no significant difference under soils of Teak and Jatropha plantation but among the different vegetation types, there was significant difference. There was a positive and significant correlation between $\mathrm{Ca} 2+$ and Silt $(\mathrm{r}=0.60)$, and between $\mathrm{Mg} 2+$ and Clay $(\mathrm{r}=0.60)$. Numerically, Forestland has the highest average $\mathrm{Ca} 2+$ and $\mathrm{Mg} 2+$ contents with mean composition of 1.09 $(\mathrm{cmol}(+) / \mathrm{kg})$ and $0.36(\mathrm{cmol}(+) / \mathrm{kg})$ respectively, while Farmland has the least average $\mathrm{Ca} 2+$ content with mean composition of $0.57 \%$, and both plantations have the least average $\mathrm{Mg} 2+$ content with mean composition of $0.18(\mathrm{cmol}(+) / \mathrm{kg})$.

Both Teak plantation and Farmland showed no significant differences in Potassium $(\mathrm{K}+)$ and sodium $(\mathrm{Na}+)$. Likewise, Forestland and Jatropha plantation showed no significant differences in sodium. However, there was significant difference among the four vegetation types in both $\mathrm{K}+$ and $\mathrm{Na}+$ contents. Numerically, the highest average $\mathrm{K}+$ and $\mathrm{Na}+$ contents were recorded under Forestland $(0.43(\mathrm{cmol}(+) / \mathrm{kg}))$ and Jatropha plantation $(0.15(\mathrm{cmol}(+) / \mathrm{kg}))$ respectively, while the least average $\mathrm{K}+$ and $\mathrm{Na}+$ contents were recorded under Teak plantation and Farmland with mean composition of $0.27(\mathrm{cmol}(+) / \mathrm{kg})$ for $\mathrm{K}+$ and $0.06(\mathrm{cmol}(+) / \mathrm{kg})$ for $\mathrm{Na}+$ as showed in Table 3. From Table 4, Na+ and $\mathrm{K}+$ were negatively correlated $(\mathrm{r}=-0.64)$ with each other. 
Effect of Vegetation Types on the Physicochemical Properties of Soils under Different Land Use

Table3. Exchangeable bases $(\mathrm{cmol}(+) / \mathrm{kg})$ as influenced by the vegetation types in the study area

\begin{tabular}{|c|c|c|c|c|c|}
\hline Parameters & Locations & Mean & $\begin{array}{c}\text { Std. } \\
\text { Deviation }\end{array}$ & F-value & $p$-value \\
\hline $\mathbf{C a}$ & Teak Plantation & $0.85 a$ & \pm 0.02 & 367.17 & 0.000 \\
\hline & Forestland & \multicolumn{2}{|c|}{$1.09 \mathrm{~b}$} & \multicolumn{2}{|c|}{ \pm 0.02} \\
\hline & Jatropha Plantation & \multicolumn{2}{|c|}{$0.80 \mathrm{a}$} & \multicolumn{2}{|c|}{ \pm 0.02} \\
\hline & Farmland & \multicolumn{2}{|c|}{$0.57 \mathrm{c}$} & \multicolumn{2}{|c|}{ \pm 0.01} \\
\hline \multirow[t]{4}{*}{ Mg } & Teak Plantation & $0.18 \mathrm{a}$ & \pm 0.01 & 160.17 & 0.000 \\
\hline & Forestland & \multicolumn{2}{|c|}{$0.36 \mathrm{~b}$} & \multicolumn{2}{|c|}{ \pm 0.02} \\
\hline & Jatropha Plantation & \multicolumn{2}{|c|}{$0.18 \mathrm{a}$} & \multicolumn{2}{|c|}{ \pm 0.01} \\
\hline & Farmland & \multicolumn{2}{|c|}{$0.32 \mathrm{c}$} & \multicolumn{2}{|c|}{ \pm 0.01} \\
\hline \multirow[t]{4}{*}{$\mathbf{K}$} & Teak Plantation & $0.27 \mathrm{a}$ & \pm 0.01 & 136.98 & 0.000 \\
\hline & Forestland & \multicolumn{2}{|c|}{$0.43 \mathrm{~b}$} & \multicolumn{2}{|c|}{ \pm 0.01} \\
\hline & Jatropha Plantation & \multicolumn{2}{|c|}{$0.32 \mathrm{c}$} & \multicolumn{2}{|c|}{ \pm 0.01} \\
\hline & Farmland & \multicolumn{2}{|c|}{$0.27 \mathrm{a}$} & \multicolumn{2}{|c|}{ \pm 0.01} \\
\hline \multirow[t]{4}{*}{$\mathbf{N a}$} & Teak Plantation & $0.06 \mathrm{a}$ & \pm 0.01 & 73.20 & 0.000 \\
\hline & Forestland & \multicolumn{2}{|c|}{$0.13 \mathrm{~b}$} & \multicolumn{2}{|c|}{ \pm 0.01} \\
\hline & Jatropha Plantation & \multicolumn{2}{|c|}{$0.15 b$} & \multicolumn{2}{|c|}{ \pm 0.01} \\
\hline & Farmland & \multicolumn{2}{|c|}{$0.06 a$} & \multicolumn{2}{|c|}{ \pm 0.01} \\
\hline
\end{tabular}

Means with the same letters are not significantly different from each other.

\subsection{Responses of Correlation Matrix among Soil Parameters}

Table 4 shows the result of correlation among the soil parameters. There was significant and positive correlation between silt particles and organic carbon, total nitrogen, available phosphorus, calcium as well as potassium with correlation coefficients (r-values) of $0.66,0.61,0.65,0.60$ and 0.64 respectively. However, correlation between silt particles and $\mathrm{pH}(\mathrm{H} 2 \mathrm{O})$ was negatively significant with a correlation coefficient of $r=-0.59$.

Clay content had significant and positive correlation with total nitrogen $(r=0.59)$ and magnesium $(r=$ $0.64)$, while sand particles was significantly positive with $\mathrm{pH}(\mathrm{H} 2 \mathrm{O})(\mathrm{r}=0.68)$ and negative with magnesium $(\mathrm{r}=-0.62)$. Of all the soil parameters, the correlation between available phosphorus and organic carbon $(\mathrm{r}=0.98)$ was the strongest. However, sand particles and $\mathrm{pH}(\mathrm{H} 2 \mathrm{O})$ had the strongest, positive and significant correlation $(\mathrm{r}=0.68)$. This was followed by that between silt and organic carbon $(\mathrm{r}=0.66)$, and the resulting correlations were also significant. The weakest and insignificant correlation was between sodium and $\mathrm{pH}(\mathrm{H} 2 \mathrm{O})$ with correlation coefficient of $\mathrm{r}=-0.01$ as shown in Table 4.

Table4. Pearson's correlation matrix among the various soil physicochemical parameters

\begin{tabular}{|c|c|c|c|c|c|c|c|c|c|c|c|}
\hline Silt & Clay & Sand & pH (H2O) & OC & TN & AP & \multicolumn{2}{|c|}{ Ca } & Mg & Na & K \\
\hline SILT & 1.00 & & & & & & & & & & \\
\hline CLAY & 0.34 & 1.00 & & & & & & & & & \\
\hline SAND & -0.84 & -0.80 & 1.00 & & & & & & & & \\
\hline $\begin{array}{c}\text { pH } \\
\text { (H2O) }\end{array}$ & $-0.59^{*}$ & -0.52 & $0.68^{*}$ & 1.00 & & & & & & & \\
\hline OC & $0.66^{*}$ & 0.85 & -0.92 & $-0.70^{*}$ & 1.00 & & & & & & \\
\hline TN & $0.61^{*}$ & $0.59^{*}$ & -0.73 & -0.41 & 0.81 & 1.00 & & & & & \\
\hline AP & $0.65^{*}$ & 0.81 & -0.88 & $-0.64^{*}$ & 0.98 & 0.91 & 1.00 & & & & \\
\hline Ca & $0.60^{*}$ & 0.73 & -0.81 & -0.46 & 0.92 & 0.95 & 0.97 & 1.00 & & & \\
\hline $\mathbf{M g}$ & 0.44 & $0.60^{*}$ & $-0.62^{*}$ & -0.81 & 0.52 & 0.08 & 0.40 & 0.18 & 1.00 & & \\
\hline $\mathbf{N a}$ & 0.06 & 0.52 & -0.38 & -0.01 & 0.54 & 0.30 & 0.50 & 0.55 & -0.03 & 1.00 & \\
\hline $\mathbf{K}$ & $0.64^{*}$ & 0.82 & -0.89 & $-0.69^{*}$ & 0.96 & $0.65^{*}$ & 0.90 & 0.82 & $0.58^{*}$ & $0.64^{*}$ & 1.00 \\
\hline
\end{tabular}

* Correlation is significant at 0.05 level

\section{DISCUSSION}

\subsection{Soil Physical Properties}

The results of the study revealed that the textural class of all the vegetation types was loamy sand (Table 1), indicating the similarity in parent material under the same climate. Irrespective of vegetation type, the particle sizes in the four land uses were dominated by sand fraction. The result of 
this study is in accordance with Oguike and Mbagwa (2009), who reported that high sand fraction, could be attributed to the parent material (coastal plain sand) since the texture of the soil is highly influenced by the parent material and topography over time. Similar case was reported by Fagbami and Udoh, (1982) and Senjobi (2007), who noted that the high percentage of sand fraction is a good indication of the observable high infiltration rate and low water holding capacity of the soils, thereby resulting into moisture stress. In addition to the above, this scenario encourages rapid leaching of nutrients from the soils beyond the rooting zones of the planted crops - a situation that threatens increase in food productivity and food security.

The mean percent of silt particle in all the vegetation types had no significant different when compared to the particles of clay and sand mean percent (Table 1). This may be as a result of little leaching and runoff water encounter which has no significant impact on the silt particles. This report is in accordance with Miles, (1985) and Sharma and Yogender, (2004). They reported that vegetation has a pronounced effect on many soil properties in which when a population of one species is replaced by plant of another species, significant change in dynamic properties of surface and subsurface soils can be expected, and with time, changes in soil structure, thickness, horizon and colour.

Clay soil content was lower in farmland and teak plantation as compared to the forestland and Jatropha plantation. The reason could be attributed either to selective removal of clay from the surface by erosion, or intensive and continuous cultivation which might cause compaction on the surface that reduces translocation of clay particles within the different layers in agreement with the findings reported by Wakene (2001) and Jaiyeoba (2001). Similarly, Eyayu et al., (2009) and Mojiri et al., (2012) reported lower clay content in cultivated land than the adjacent soils under natural forest.

\subsection{Soil Chemical Properties}

The soil Organic Carbon content varied among the vegetation types with higher amount of Organic Carbon in Forestland compared to others. This could be attributed to improved aeration that promoted mineralization of $\mathrm{OC}$ or owing to the little or no return of plant residues and manures into the soils. Also, high temperature and high relative humidity, which favour rapid mineralization, might be responsible for decreasing order of magnitude of Organic Carbon (FO > TP > JP > FL) in conformation with the finding of Senjobi and Ogunkunle (2011).

Much of farmland loss in soil Organic Carbon can be attributed to reduced inputs of organic matter, decreased decomposability of crop residues, and tillage effects that decrease the amount of physical protection to decomposition as reported by Post and Kwon, (2000). Offiong and Iwara, (2012) also reported that the conversion of forest ecosystem to other forms of land cover may decrease the stock of OC due to changes in soil moisture and temperature regimes, and succession of plant species with differences in quantity and quality of biomass returned to the soil. Shukla et al., (2006) reported that Organic Carbon is a powerful indicator for assessing soil potential productivity, and a great number of studies have reported similar observations. Paustian et al., (1996) observed that a greater frequency of cropping with associated increases in SOC is due to greater return of crop residues.

The significant differences $(p=0.00)$ in soil Organic Carbon among the different vegetation types indicate a drastic reduction in the organic Carbon content, structural stability and nutrients content of the soils in the study area. With respect to global climate change as reported by Barrow (2006) and Khresat et al., (2008), who noted that the destruction of forests due to anthropogenic activities and enforced processes of Organic Carbon decomposition contribute to increased emissions of $\mathrm{CO} 2$ into the atmosphere.

Total Nitrogen richness under Forestland in the study area could be attributed to the land use and management system, as roughly $95 \%$ of soil total Nitrogen is found in soil organic material in undisturbed, natural soils. This is in accordance to the report stated by Price et al., (2010) and Walworth, (2013). The TN content of the soils ranged from 0.35 to $0.76 \%$ (Table 2); this range of value was rated as medium when compared to the medium range of 0.10 to $0.45 \%$ recommended by Holland et al., (1989) and Deekor (2012). This range is however, consistent with the works of Ukaegbu and Akamigbo (2005) who reported average TN percentage of 0.08 in soils of the Cross River Coastal plain sands. Ayoubi et al., (2011) reported that natural forest soils had more TN as compared to the cultivated lands. Likewise, Heluf and Wakene (2006) recorded the highest TN on surface soil layers of virgin lands compared to research and farmers' fields. 
The least total Nitrogen value recorded in farmland may be attributed to the intense cultivation of the soils which normally decrease the rate of mineralization of the organic matter. Franzluebbers et al., (1999) reported that increase in the intensity and frequency of tillage operations which produces more soil disturbance decreased total Nitrogen content. The increase in the contents of OC and TN under forestland is attributable to the increase in plant density and cover which provides large amount of biomass that decomposes to form nutrient in the soil.

The significant difference in available Phosphorus of the soil under the different vegetation type could be attributed to organic material deposit, the rate of mineralization and leaching. Content of AP in all the vegetation types ranged from $0.34-1.32 \mathrm{mg} / \mathrm{kg}$ revealing that all soils of the study area were deficient in AP as in accordance to Thomas (2000). Bubba et al., (2003) reported that the causes of available phosphorus deficiencies have been attributed to high weather ability of the soils, clay type, leaching by intense rainfall and adsorption reaction by soil constituents.

Yeshaneh (2015) reported that the availability of phosphorus under most soils decline by the impacts of fixation, abundant crop harvest and erosion. Among the vegetation types, forestland contained relatively higher concentration of AP as a result of high organic matter which released phosphorus during its mineralization.

Soil reactions $(\mathrm{pH})$ values measured in a suspension of soil to water ratio are greater than that of soil to $\mathrm{KCl}$ solution ratio. Soil $\mathrm{pH}$ of the study area are moderately acidic to neutral (6.30-7.17) for soil $\mathrm{pH}$ $(\mathrm{H} 2 \mathrm{O})$, and slightly acidic to moderately acidic (5.30-6.47) for soil $\mathrm{pH}(\mathrm{KCl})$. The sequence of increase in soil reactions among the vegetation types is JP > TP > FL > FO. Lower soil pH (H2O) in the forestland could be attributed to increased nutrient uptake resulting from soil acidification, and organic acids released by litter decomposition. This is in conformity with the findings of Brady and Weil (2007) in USA. Similar case has been reported by Yoshinori et al., comparison of physicochemical properties of soils under contrasting land use systems in Southwestern Nigeria. Mohammed et al., (2005) also reported that the relative decline in soil $\mathrm{pH}$ under natural forest land could be due to oblong shaped canopy leading the rain to form big drops consequently enhancing leaching of basic cations as well as releasing organic acids associated with mineralization of organic matter.

The slightly lower average value of soil $\mathrm{pH}$ under farmland may be attributed to continuous cultivation which increase losses associated with lowering of organic matter and organic Carbon contents in the soil. Chimdi et al., (2014) reported that slightly lower $\mathrm{pH}$ value in farmland may be due to the depletion of basic cations in crop harvest, and due to its highest microbial oxidation that produces organic acids, which provide $\mathrm{H}+$ to the soil solution lowers its soil $\mathrm{pH}$ value. As reported by Wasihun and Muktar (2015), that continuous cultivation practices, excessive precipitation, and application of inorganic fertilizers could be some of the factors which are responsible for the variation in $\mathrm{pH}$ in the soil profiles.

There were significant differences in the concentration of exchangeable $\mathrm{Ca} 2+, \mathrm{Mg} 2+, \mathrm{K}+$ and $\mathrm{Na}+$ among the different vegetation types. This may be attributed to leaching losses, low content in the parent rock and the proportion of clay minerals as well as the conversion of forestland into the other land use types. This study is in agreement with the findings of Wakene and Heluf (2003), who reported that continuous cultivation and use of acid forming inorganic fertilizers deplete exchangeable $\mathrm{Ca} 2+$ and $\mathrm{Mg} 2+$.

The proportions of exchangeable bases $\mathrm{Ca}, \mathrm{Mg}$, and $\mathrm{K}$ were low across the studied soils. This finding agrees with the works of Akinrinde and Obigbesan, 2000; Uzoho et al., 2007, who reported low values of $\mathrm{Ca}, \mathrm{Mg}$ and $\mathrm{K}$ for most Nigerian soils, and are attributed to leaching losses by the high tropical rainfall as well as low content in the parent rock. The low exchangeable potassium contents observed under cultivated land could be due to continuous cultivations and inorganic farming practices in the study area. This is in line with Malo et al., (2005), who indicated intensity of weathering, cultivation and use of acid forming inorganic fertilizers affect the distribution of potassium on farmland, thus, enhancing its depletion.

Concentration of sodium in all the vegetation types is below the critical limit $(1.0(\mathrm{cmol}(+) / \mathrm{kg}))$, thus, the soils have sodicity problem. This is in conformity with the work of Uquetan et al., (2017) in Akampa, Cross River state. In general, deforestation, leaching, limited recycling of dung and crop 
residue in the soil, very low use of chemical fertilizers, declining fallow periods or continuous cropping and soil erosion have contributed to depletion of exchangeable bases.

\section{CONCLUSION}

The result of this finding revealed that, the vegetation types under different land uses have influenced the soil physical and chemical properties at a different level. The results of this study are evidences of significant changes in the quality attributes of the soils in the study area, following the removal of vegetative cover and frequent tillage that lead to soil erosion, thereby declining soil fertility. The direct causes of land degradation, including decline in the use of fallow, limited recycling of dung and crop residues to the soil, limited application of external sources of plant nutrients, and deforestation are apparent. Most parameters of the soil under farmland vegetation showed overall changes towards the direction of fertility loss compared to the parameters of the other vegetation types. Soil under forest reserve (forestland) recorded high level of organic carbon, total nitrogen, available phosphorus, calcium, magnesium, potassium, silt and clay particles over soils under teak plantation, Jatropha plantation and farmland. This resulted from high content of organic materials, a dense vegetative cover which mitigates erosion effects, found in the forestland. Likewise, forestland soil was more acidic among the different land uses. Irrespective of vegetation type, it was observed that soil particle sizes did not vary among the studied soils. However, soils of Jatropha plantation and farmland are more sandy, while teak plantation and farmland had the lowest clay content. From the present study, it could be concluded that the soil quality and health were maintained relatively under the forest rserve, whereas, the influence on most parameters were very low on the soil farmland, suggesting the need for intervention so as to optimize and sustain the soil quality.

Thus, it is recommended that management practices such as planting leguminous crops, increased fallow period, organic manuring, planting of fast growing vegetative species and returning crop residues to the soil as a way of building up used carbon stocks on farmland. Also, Techniques complemented with strong land-use policy should be integrated into the strategy for sustainable agricultural development in the study area. The management should enlighten the land users, particularly the farmers, on soil conservation practices through detailed soil survey and land evaluation. When this is carefully done, the soil can then be put to appropriate land use by land users, having known its capability and constraints as well as use the land for the purpose it is best suited for, this will go a long way to improve the productivity of such lands, thus, directly or indirectly maintaining the quality of the soil.

\section{REFERENCES}

[1] Abad, J. R. S., Khosravi, H. and Alamdarlou, E. H. (2014): Assessment of the effects of land use changes on soil physicochemical properties in Jafarabad of Golestan Province, Iran. Bulletin of Environment, Pharmacology and Life Sciences 3(3): 296 - 300.

[2] Adetunji, M. T. (2004): Integrated soil nutrient management options for Nigerian Agriculture. Proceedings of the 29th Annual Conference of the Soil Science Society of Nigeria pp. 27- 34.

[3] Akinrinde, E. A. and Obigbesan, G. O. (2000): Evaluation of fertility status of selected soils for crop production in five ecological areas of Nigeria. 26th Annual Conference of the Soil Science Society of Nigeria pp. 279-288.

[4] Ayoubi, S., Khormali, F., Sahrawat, K. L., and Rodrigues de Lima, A. C. (2011): Assessing Impacts of Land Use Change on Soil Quality Indicators in a Loessial Soil in Golestan Province, Iran; Journal of Agricultural Science and Technology 13: 727- 742.

[5] Black, C. A. (1965): Methods of soil analysis; American Society of Agronomy 1572p.

[6] Bouyoucos, G. J. (1962): Hydrometer method improvement for making particle size analysis of soils. Journal of agronomy 54: 179-186.

[7] Brady, N. C. and Weil, R. R. (2007): The nature and properties of soils; 13th edition. 960p.

[8] Bubba, M. O., Arias, C. A. and Briax, H. (2003): Phosphorus Adsorption maximum of sands for use as media in subsurface flow cultivated reed beds as measured by Langmuir isotherm; Water Research 37: $3390-3400$.

[9] Chapman, H. D. (1965): Cation Exchange capacity: Methods of soil analysis. Agronomy 9: 891-901.

[10] Day, P. R. (1965): Hydrometer method of particle size analysis. American Society of Agronomy.

[11] Deekor, T. N. (2012): Changes in soil properties under different land use covers in parts of Odukpani, Cross River state, Nigeria. Journal of environment and ecology 3 (1): 2157 - 6092. 
[12] Eyayu, M., Heluf, G., Tekaliign, M. and Mohammed, A. (2009): Effects of land-use change on selected soil properties in the Tera Gedam Catchment and adjacent agroecosystems, north-west Ethiopia. Ethiopian Journal of Natural Resources 11(1): 35-62. 75

[13] Fagbami, A. and Udoh, E. J. (1982): The Characteristics of two soils toposequencies in the basement complex in the Federal Capital Territory of Nigeria. Ife Journal of Agriculture 4(112): 9-24.

[14] Franzluebbers, A. J., Langdale, G. W. and Schomberg, H. H. (1999): Soil Carbon, Nitrogen, and aggregation in response to type and frequency of tillage. Soil Science Society of American Journal 63(2): 349-355.

[15] Gee, G. W. and Bauder, J. W. (1986): Particle size analysis, 2nd Edition; Agronomy 383- 411.

[16] Heluf Gebrekidan and Wakene Negassa (2006): Impact of Land use and management practices on chemical properties of some soils of Bako area, Western Ethiopia. Ethiopian Journal of Natural Resources $8(2): 177-197$.

[17] Holland, M. D., Allen, R. K. G., Barten, D. and Murphy, S. T. (1989): Land Evaluation and Agricultural Recommendations for Cross River National Park, Oban Division. Report Prepared by the Overseas Development Resources Institute in Collaboration with WWF for the Federal Republic of Nigeria and the Cross River State Government.

[18] Jaiyeoba, I. A. (2001): Soil rehabilitation through afforestation. Land degradation and development 12: 183-194.

[19] Malo, D. D., Schumacher, T. E. and Doolittle, J. J. (2005): Long-term cultivation impacts on selected soil properties in the northern Great Plains. Soil Tillage Research 81: 277-291.

[20] Miles, J. (1985): The pedegenic effects of different species and vegetation types. Journal of Soil Science 36: 571-584.

[21] Mohammed, A. P., Le Roux, A. L., Barker, C. H., and Heluf, G. (2005): Soils of Jelo Micro- Catchment in the Chercher highlands of Eastern Ethiopia. Ethiopia Journal of Natural Resources 7(1): 55-81.

[22] Mojiri, A., Aziz, H. A. and Ramaji, A. (2012): Potential decline in soil quality attributes as a result of land use change in a hill slope in Lordegan, Western Iran. African Journal of Agricultural Research 7(4): 577 582.

[23] Oguike, P. C. and Mbagwu, J. S. C. (2009): Variations in some physical properties and organic matter content of soils of coastal plain sand under different land use types. World Journal of Agricultural Science 5: 63-69.

[24] Olanrewaju, R. M. (2009): Climate and the Growth Cycle of Yam Plant in the Guinea Savannah Ecological Zone of Kwara State. Nigeria Journal of Meteorology and Climate Science 2(2): 43-48.

[25] Olsen, S. R., Cole, C. V., Watanable, F. S. and Dean, L. A. (1954): Estimation of Available Phosphorus in soil by extraction with Sodium bicarbonate. USDA Circular 939: 1- 19.

[26] Oyeyiola, G. P. and Agbaje, A. B. (2013): Physicochemical Analysis of a Soil near Microbiology Laboratory at The University of Ilorin, Main Campus. Journal of Natural Sciences Research 3: 78-81.

[27] Paustian, K., Collins, H. P. and Paul, E. A. (1996): Management controls on soil carbon. CRC Press pp. 15-50.

[28] Post, W. M. and Kwon, K. C. (2000): Soil Carbon sequestration and land-use change: process and potential. Global Change Biology 6(3): 317-327.

[29] Price, K., Jackson, C. R. and Parker, A. J. (2010): Variation of surficial soil hydraulic properties across land uses in the southern Blue Ridge Mountains. Journal of Hydrology 383(3-4): 256-268.

[30] Reeuwijk, L. P. V (2002): Procedures for soil analysis, 6th Edition. International Soil Reference and Information Center (ISRIC).

[31] Rowell, D. L. (1994): Soil science: Methods \& Applications. Addison Wesley Longman Singapore Publishers 350p.

[32] Senjobi, B. A. (2007): Comparative assessment of the effect of land use and land type on soil degradation and productivity in Ogun State, Nigeria. Department of Agronomy, University of Ibadan, Ibadan, pp. 161.

[33] Senjobi, B. A. and Ogunkunle, A. O. (2011): Effect of different land use types and their implications on land degradation and productivity in Ogun State, Nigeria. Journal of Agricultural Biotechnology \& Sustainable Development 3(1):7-18.

[34] Shukla, M. K., Lal, R., and Ebinger, M. (2006): Determining Soil Quality Indicators by Factor Analysis. Soil Tillage Research, 87: 194-204.

[35] Thomas, S. J. (2000): Soil fertility evaluation. Sumner Handbook of soil science. pp. 159- 164.

[36] Tilahun, G. (2007): Soil fertility status as influenced by different land uses in Maybar areas of South Wello Zone, North Ethiopia. Haramaya University, 84p. 
[37] Ukaegbu, E. P. and Akamigbo, F. O. R. (2005): Influence of Physiography on the Properties and Use of Soils of the Cross River Plain: A Case Study of a Strip of Land at Isiagu, Ebonyi State. Proceedings of 29th Annual Conference of Soil Science Society Nigeria. p103 - 109.

[38] Uquetan, U. I., Eze, E. B., Uttah, C., Obi, E. O., Egor, A. O. and Osang J. E. (2017): Evaluation of soil quality in relation to Land use effect in Akampa, Cross River state, Nigeria. Applied Ecology and Environmental Sciences 2(5): 35-42.

[39] Uzoho, B. U., Oti, N. N. and Ngwuta, A. (2007): Fertility Status under land use types on Soils of Similar Lithology. Journal of American Science, 3(4), 20 - 29. 87

[40] Van Reeuwijk, L. P. (1992): Procedures for soil analysis, 3rd Edition. International Soil Reference and Information Center (ISRIC) 34p.

[41] Wakene, Negassa (2001): Assessment of important physicochemical properties of Dystric Udalf under different management systems in Bako area, western Ethiopia. School of Graduate Studies, Alemaya University pp. 93. Wakene N. C. and Heluf, G. (2003): The impact of different land use systems on soil quality of Western Ethiopian Alfisols. Bako Agricultural Research Centre. Pp 2-6.

[42] Walkley, A. J. and Black, I. A. (1934): Estimation of Soil Organic Carbon by chromic acid titration method. Soil Science 37: 29-38.

[43] Walworth, J. (2013): Nitrogen in Soil and Environment. The University of Arizona, College of Agriculture and Life Sciences, Cooperative Extension: AZ159.

[44] Wasihun M. and Muktar (2015): Evaluation of the Effect of Land Use Types on Selected Soil Physicochemical Properties in Itang-Kir Area of Gambella Region, Ethiopia. Journal of Biology, Agriculture and Healthcare 11: 2224-3208.

Citation: Amonum. J. I., et.al, "Effect of Vegetation Types on the Physicochemical Properties of Soils under Different Land Use", International Journal of Forestry and Horticulture, 6(2), pp. 16-25. DOI: http://dx.doi.org/10.20431/2454-9487.0602002

Copyright: (C) 2020 Authors, This is an open-access article distributed under the terms of the Creative Commons Attribution License, which permits unrestricted use, distribution, and reproduction in any medium, provided the original author and source are credited. 